\title{
Aluminum species and activity in sandy soil solution with pig slurry addition
}

\author{
Lessandro De Conti( ${ }^{(1)}$, Carlos Alberto Ceretta( ${ }^{(1)}$, Rafael da Rosa Couto(1), \\ Paulo Ademar Avelar Ferreira ${ }^{(1)}$, Lincon Oliveira Stefanello da Silva(1), Rogério Piccin ${ }^{(1)}$, \\ Cledimar Rogério Lourenzi(2), Eduardo Girotto ${ }^{(3)}$ and Gustavo Brunetto(1)
}

\begin{abstract}
(1)Universidade Federal de Santa Maria, Centro de Ciências Rurais, Departamento de Solos, Avenida Roraima, no 1.000, Cidade Universitária, Camobi, CEP 97105-900 Santa Maria, RS, Brazil. E-mail: lessandrodeconti@gmail.com, carlosceretta@ufsm.br, rrccouto@hotmail.com, ferreira.aap@gmail.com, linconfa@hotmail.com, piccinagro@gmail.com, brunetto.gustavo@gmail.com (2)Universidade Federal de Santa Catarina, Centro de Ciências Agrárias, Departamento de Engenharia Rural, Rodovia Admar Gonzaga, no 1.346, Itacorubi, CEP 88034-000 Florianópolis, SC, Brazil. E-mail: lourenzicr@gmail.com ${ }^{(3)}$ Instituto Federal de Educação, Ciência e Tecnologia do Rio Grande do Sul, Rua Nelsi Ribas Fritsch, № 1.111, Esperança, CEP 98200-000 Ibirubá, RS, Brazil. E-mail: eduardo.girotto@ibiruba.ifrs.edu.br
\end{abstract}

\begin{abstract}
The objective of this work was to evaluate the effect of pig slurry applications on the exchangeable $\mathrm{Al}$ content, activity, and distribution of Al chemical species in the soil solution. Soil samples of a Typic Hapludalf were obtained from an experiment conducted during eight years, with 19 applications of 0,20 , 40 , and $80 \mathrm{~m}^{3} \mathrm{ha}^{-1}$ pig slurry. The soil samples were collected in stratified layers to determine exchangeable $\mathrm{Al}$ content and to extract the soil solution by the saturated soil paste method. The concentrations of the main cations and anions, dissolved organic carbon, and $\mathrm{pH}$ in the soil solution were determined. The distribution of the chemical species of $\mathrm{Al}$ and the activity of the $\mathrm{Al}^{3+}$ species were obtained through the Visual Minteq software. The application of pig slurry does not change the exchangeable $\mathrm{Al}$ content in the soil and the $\mathrm{Al}^{3+}$ activity in the soil solution. The low $\mathrm{Al}^{3+}$ activity in the topsoil layers does not present risk of toxicity for most crops. Pig slurry applications increase the proportion of the $\mathrm{AlHPO}_{4}{ }^{+}$and $\mathrm{AlSO}_{4}{ }^{+}$species in the soil solution, by increasing the concentration of soluble inorganic ligands.
\end{abstract}

Index terms: inorganic ligand, organic amendment, phytotoxicity, soil solution.

\section{Espécies e atividade de alumínio na solução de solo arenoso com adição de dejetos líquidos de suínos}

Resumo - O objetivo deste trabalho foi avaliar o efeito das aplicações de dejetos líquidos de suínos no teor de $\mathrm{Al}$ trocável, na atividade e na distribuição das espécies químicas de $\mathrm{Al}$ na solução do solo. Amostras de um Argissolo foram obtidas de um experimento conduzido durante oito anos, com 19 aplicações de $0,20,40$ e 80 $\mathrm{m}^{3} \mathrm{ha}^{-1}$ de dejetos líquidos de suínos. As amostras de solo foram coletadas em camadas, para determinação do $\mathrm{Al}$ trocável e extração da solução do solo pelo método da pasta de saturação. Na solução, foram determinados as concentrações dos principais cátions e ânions, o carbono orgânico dissolvido e o pH. A distribuição das espécies químicas de $\mathrm{Al} \mathrm{e}$ a atividade da espécie $\mathrm{Al}^{3+}$ foram obtidas pelo programa Visual Minteq. A aplicação de dejetos líquidos de suínos não altera o teor de $\mathrm{Al}$ trocável no solo e a atividade de $\mathrm{Al}^{3+}$ na solução do solo. A baixa atividade de $\mathrm{Al}^{3+}$ nas camadas superficiais não apresenta risco de toxidez para a maioria das culturas. A adição de dejetos líquidos de suínos aumenta a proporção das espécies $\mathrm{AlHPO}_{4}{ }^{+}$e $\mathrm{AlSO}_{4}{ }^{+}$na solução do solo, por incrementar a concentração de ligantes inorgânicos solúveis.

Termos para indexação: ligante inorgânico, adubação orgânica, fitotoxicidade, solução do solo.

\section{Introduction}

Commercial pig farming in Brazil is characterized by confinement in all stages of production, concentrating a large number of animals in small areas, which generates large amounts of waste that need to be discarded. In Rio Grande do Sul, which is the second largest pig farming state in the country, an estimated $38,000 \mathrm{~m}^{3}$ pig slurry (PS) is produced daily (Fepam, 2008). This waste is mainly disposed of by the application in agricultural areas as a source of nutrients to crops (Lourenzi et al., 2013; De Conti et al., 2016).

The application of manure or organic waste in agricultural areas modifies the availability of essential and non-essential elements by simultaneously adding numerous chemicals, including carbon. However, elements, such as aluminum, may be potentially toxic to plants, even at low concentrations (Vieira et al., 
2009; Veiga et al., 2012). Weathered soils of tropical and subtropical regions are naturally acidic and already have a high content of exchangeable Al, which may be toxic to plants, reducing crop growth and yield (Vieira et al., 2009; Alleoni et al., 2010; Rutkowska et al., 2015).

The Al in the soil solution can be in the free form or forming complexes, ionic pairs, or chelates with ions or molecules of opposite valence, modifying its bioavailability and, consequently, phytotoxic potential (Nogueirol et al., 2015). Al bioavailability depends on the present soluble chemical species, with reducing negative effect of $\mathrm{Al}$ monomeric species on the crop root system, as follows: $\mathrm{Al}^{3+}>\mathrm{AlOH}^{2+}>\mathrm{Al}(\mathrm{OH})_{2}{ }^{+}>$ $\mathrm{Al}(\mathrm{OH})_{3}{ }^{0}>\mathrm{Al}(\mathrm{OH})_{4}{ }^{-}>\mathrm{Al}\left(\mathrm{SO}_{4}\right)^{+}$(Bloom \& Erich, 1995; Rutkowska et al., 2015). However, Al species complexed with fluoride, organic compounds, and phosphate are not considered harmful to living organisms (Nolla \& Anghinoni, 2006; Nogueirol et al., 2015).

The application of slurry may be useful for alleviating $\mathrm{Al}$ toxicity in acidic soils, due to the increase in soil $\mathrm{pH}$ and in nutrient availability, as well as to the formation of Al organic and inorganic complexes (Rutkowska et al., 2015). Vieira et al. (2009) reported the decreased activity of toxic Al species in the soil solution of an acidic sandy soil with the application of organic compost.

Managementpractices thatincrease the concentration of soluble ligands and nutrients, such as liming and organic amendment, tend to reduce the percentage and activity of $\mathrm{Al}^{3+}$ species in the soil solution, reducing its toxicity to plants. This is observed in soils under no-tillage, where the maintenance of organic residues increased the concentration of organic ligands in the topsoil, keeping available $\mathrm{Al}^{3+}$ low, even in acidic conditions (Nolla \& Anghinoni, 2006; Alleoni et al., 2010). Therefore, the benefits of pig slurry application to crops cannot be restricted only to the increase in nutrient availability, also being related to the reduction in the availability of non-essential, potentially toxic elements, such as Al.

The objective of this work was to evaluate the effect of pig slurry applications on the exchangeable Al content, activity, and distribution of chemical species of $\mathrm{Al}$ in the soil solution.

\section{Materials and Methods}

The soil was obtained from an experiment conducted from 2000 to 2008 at Universidade Federal de Santa Maria, located in the municipality of Santa Maria, in the state of Rio Grande do Sul, Brazil (29 43'12"S, 53\%43'4"W), in which pig slurry was applied 19 times during eight years. The experiment was carried out under no-tillage on a Argissolo Vermelho distrófico arênico (Santos et al., 2013), i.e., a sandy Typic Hapludalf, which presented the following characteristics in the $0.00-0.10-\mathrm{m}$ layer before the setup of the experiment: $170 \mathrm{~g} \mathrm{~kg}^{-1}$ clay; $300 \mathrm{~g} \mathrm{~kg}^{-1}$ silt; $530 \mathrm{~g} \mathrm{~kg}^{-1}$ sand; $16 \mathrm{~g} \mathrm{~kg}^{-1}$ organic matter; $4.7 \mathrm{pH}$ in water; $15 \mathrm{mg} \mathrm{kg}^{-1}$ available $\mathrm{P}$ and $96 \mathrm{mg} \mathrm{kg}^{-1}$ exchangeable $\mathrm{K}$ (both extracted by Mehlich-1); and $0.8,2.7$, and $1.1 \mathrm{cmol}_{\mathrm{c}} \mathrm{dm}^{-3}$ exchangeable $\mathrm{Al}, \mathrm{Ca}$, and $\mathrm{Mg}$, respectively (extracted by $\mathrm{KCl} 1.0 \mathrm{~mol} \mathrm{~L}^{-1}$ ) (Lourenzi et al., 2013). The following crop sequences were grown: black oat (Avena strigosa Schreb.), corn (Zea mays L.), and turnip (Raphanus sativus L.) in 2000/2001 and 2001/2002; black oat, pearl millet [Pennisetum americanum (L.) K.Schum.], and black bean (Phaseolus vulgaris L.) in 2002/2003; black oat + vetch (Vicia sativa L.) and corn in 2003/2004 and 2004/2005; black oat, black bean, and brown hemp (Crotalaria juncea L.) in 2005/2006; and black oat and corn in 2006/2007. The treatments consisted of a total of 19 pig slurry applications, as the only source of nutrients, by surface broadcasting at the doses of 0,20 , 40 , and $80 \mathrm{~m}^{3} \mathrm{ha}^{-1}$ preceding each crop planting, during eight years of cultivation. Pig slurry was applied twice in the 2003/2004 and 2004/2005 crop years, but three times in the other ones. The experimental design was randomized complete blocks with three replicates.

The total concentrations of nitrogen, phosphorus, and potassium in the pig slurry were measured after digestion of $2.0-\mathrm{mL}$ samples in natura with $2.0 \mathrm{~mL} \mathrm{H}_{2} \mathrm{SO}_{4}$ and $1.0 \mathrm{~mL} \mathrm{H}_{2} \mathrm{O}_{2}$ (Tedesco et al., 1995). For determinations of total calcium, magnesium, copper, and zinc, the pig slurry was oven-dried at $65^{\circ} \mathrm{C}$ to a constant weight, in order to measure the dry matter (DM). Afterwards, $0.1 \mathrm{~g}$ was ground and digested in $3.0 \mathrm{~mL} \mathrm{HNO}_{3}$ plus $1.0 \mathrm{~mL} \mathrm{HClO}_{4}$ (Claessen, 1997). The total organic carbon content of the pig slurry was obtained from sub-samples of finely ground DM using an elemental autoanalyzer FlashEA 1112 model (Thermo Finnigan Italia S.p.A., Rodano, Milan, Italy). The amounts used in the 19 applications were determined based on the resulting concentrations of chemical elements and on the application rates of pig slurry, as shown in Table 1. 
In January 2008, seven months after the last pig slurry application, an undisturbed soil column was collected in each treatment replicate, totaling three columns per treatment. The soil was collected in polyvinyl chloride (PVC) tubes measuring $200 \mathrm{~mm}$ in diameter and $650 \mathrm{~mm}$ in length, coupled to a monolith sampler; the tubes were manually driven into the soil down to a depth of $0.6 \mathrm{~m}$. Following the collection, the ends of the soil columns were covered with dark plastic and were stored at room temperature, in the same arrangement of the layers as in the field experiment. In April 2012, the soil columns were placed on benches in a greenhouse. Then, the moisture content was restored with $112 \mathrm{~mL}$ distilled water per kilogram of soil, using plastic drippers (intravenous catheters), in order to reach field capacity, which was maintained for 30 days. Therefore, it was possible to control the intensity of water supply, preventing the accumulation of water on soil surface, which could enhance preferential flow.

After 30 days in field capacity moisture, the PVC pipe was opened laterally and stratified soil was collected at $0.00-0.05,0.05-0.10,0.10-0.20,0.20-$ $0.30,0.30-0.40$, and $0.40-0.60 \mathrm{~m}$. Soil samples were divided into two parts. The first was stored at $4^{\circ} \mathrm{C}$ for subsequent extraction of the soil solution by the saturated soil paste method, adapted from the aqueous extract proposed by Wolt (1994). In order to do so, $800 \mathrm{~g}$ soil were placed in a 1-L plastic container, to which Milli-Q water was added, with simultaneous disturbance until forming a thin film of water over the soil mass. The saturated soil remained at rest for 16 hours to achieve soil-solution balance and, then, it was placed in a Büchner funnel with qualitative filter paper with particle retention of $4-12 \mu \mathrm{m}$. The soil solution was extracted using a Kitassato suction flask attached to a funnel and a vacuum pump. The second portion of soil was air-dried, passed through a 2-mm mesh sieve, and reserved for the determination of exchangeable $\mathrm{Al}$ content.
In the extracted solution, an aliquot was removed to measure $\mathrm{pH}$ and the remainder was filtered at $0.45 \mu \mathrm{m}$. Then, the amount of dissolved organic carbon(DOC) was obtained by digestion with $0.4 \mathrm{~N}$ potassium dichromate at $60^{\circ} \mathrm{C}$ for 4 hours, with subsequent spectrophotometric procedure, at $560 \mathrm{~nm}$, using the calibration curve prepared with glucose, as described by Silva \& Bohnen (2001). The total concentrations of $\mathrm{Al}, \mathrm{Ca}, \mathrm{Mg}, \mathrm{Cu}, \mathrm{Zn}$, $\mathrm{Mn}, \mathrm{K}, \mathrm{Fe}$, and $\mathrm{P}$ were measured using an inductively coupled plasma-atomic emission spectrometer (ICP model, PerkinElmer Inc., Waltham, MA, USA), and the concentrations of $\mathrm{N}, \mathrm{S}$, and $\mathrm{Cl}$ were obtained by ion chromatography S135 model (Sykam GmbH Systeme \& Komponenten analytischer Meßtechnik, Eresing, Germany). Ion speciation in the soil solution was performed using the software Visual Minteq, version 2.15 (Gustafsson, 2012), based on the means of three replicates of the total soluble concentrations of cations $\left(\mathrm{Al}^{3+}, \mathrm{Ca}^{2+}, \mathrm{Mg}^{2+}, \mathrm{Zn}^{2+}, \mathrm{Cu}^{2+}, \mathrm{Mn}^{2+}, \mathrm{K}^{+}\right.$, and $\left.\mathrm{Fe}^{2+}\right)$, anions $\left(\mathrm{PO}_{4}{ }^{3-}, \mathrm{NO}_{3}{ }^{-}, \mathrm{SO}_{4}{ }^{2-}\right.$, and $\left.\mathrm{Cl}^{-}\right), \mathrm{DOC}$, and $\mathrm{pH}$, determined in the soil solution. The formation of metal complexes and DOC was assessed using the Gaussian dissolved organic matter (DOM) model (Grimm et al., 1991). The formation of inorganic aqueous complexes was analyzed using equilibrium constants from the default Visual Minteq database developed by Smith et al. (2003). The percentage distributions of $\mathrm{Al}$ species and $\mathrm{Al}^{3+}$ activity in the soil solution were thereby calculated. Levels of exchangeable $\mathrm{Al}$ were determined by extraction with $\mathrm{KCl} 1.0 \mathrm{~mol} \mathrm{~L}^{-1}$, followed by titration with $\mathrm{NaOH} 0.0125$ mol L-1, according to Tedesco et al. (1995).

The exchangeable contents and activity of $\mathrm{Al}^{3+}$ in the soil solution are presented as means of three replicates, followed by their standard deviation, and in logarithmic form. The principal component analysis (PCA) was performed on the mean values of the depth intervals in the soil profile of each treatment replicate using the Canoco software, version 4.5 (Braak \& Smilauer, 2002). The variables used in the analysis

Table 1. Amounts of carbon and nutrients applied via 19 applications of $0,20,40$, and $80 \mathrm{~m}^{3} \mathrm{ha}^{-1}$ pig slurry (PS), during eight years, on a Typic Hapludalf.

\begin{tabular}{|c|c|c|c|c|c|c|c|c|}
\hline $\begin{array}{l}\text { PS rate } \\
\left(\mathrm{m}^{3} \mathrm{ha}^{-1}\right)\end{array}$ & $\begin{array}{c}\text { Carbon } \\
\left(\mathrm{Mg} \mathrm{ha}^{-1}\right)\end{array}$ & $\mathrm{N}$ & $\mathrm{P}$ & -------- & $\begin{array}{c}\mathrm{Ca} \\
\left(\mathrm{kg} \mathrm{ha}^{-1}\right)\end{array}$ & $\mathrm{Mg}$ & $\mathrm{Cu}$ & $\mathrm{Zn}$ \\
\hline 0 & - & - & - & - & - & - & - & - \\
\hline 20 & 4.69 & 951 & 624 & 364 & 327 & 378 & 17.1 & 21.4 \\
\hline 40 & 9.39 & 1,902 & 1,248 & 727 & 654 & 756 & 34.2 & 42.8 \\
\hline 80 & 18.78 & 3,804 & 2,497 & 1,455 & 1,308 & 1,513 & 68.4 & 85.6 \\
\hline
\end{tabular}

Pesq. agropec. bras., Brasília, v.52, n.10, p.914-922, out. 2017

DOI: 10.1590/S0100-204X2017001000011 
were chemical parameters measured in the soil solution, percentages of $\mathrm{Al}$ chemical species, and $\mathrm{Al}^{3+}$ activity in the soil solution.

\section{Results and Discussion}

Exchangeable Al was not affected by pig slurry doses, but its contents increased in layers below $0.30 \mathrm{~m}$ in all treatments (Figure 1). The increase of exchangeable $\mathrm{Al}$ in depth is probably due to the type of soil evaluated (Hapludalf), characterized by an increase in clay content and oxides in depth caused by the presence of a textural horizon (Streck et al., 2008).

The activity of $\mathrm{Al}^{3+}\left(\log \mathrm{Al}^{3+}\right)$ in the soil solution was not altered by the application of $0,20,40$, and $80 \mathrm{~m}^{3}$ $\mathrm{ha}^{-1}$ pig slurry in the studied layers (Figure 1). The low activity of $\mathrm{Al}^{3+}$ in superficial layers probably occurred because of the superior concentrations of $\mathrm{K}, \mathrm{SO}_{4}{ }^{2-}$, and DOC in the soil solution without the addition of pig slurry, since the interactions between ions and organic molecules decrease ion activity in the soil solution, and because of the $\mathrm{Ca}, \mathrm{Mg}, \mathrm{K}, \mathrm{Cu}, \mathrm{Zn}$, and $\mathrm{P}$ contents in the soil managed with pig slurry (Table 2). The elevated concentration of macronutrients, as well as of $\mathrm{Cu}$ and
$\mathrm{Zn}$, in the soil solution was due to the addition of these elements through pig slurry application (Table 1) in concentrations above the absorption capacity of the crops, increasing their contents in the soil and soil solution (Couto et al., 2015; De Conti et al., 2016). Nolla \& Anghinoni (2006), in turn, found a decrease in $\mathrm{Al}^{3+}$ activity in more acidic conditions, with the addition of $\mathrm{P}$ doses in columns of an Oxisol managed under no-tillage.

The activity of $\mathrm{Al}^{3+}$ species indicates a low risk of toxicity for annual crops, because, at the $0.00-0.20-\mathrm{m}$ layer of all treatments, where much of the root system of these crops is concentrated (Bortoluzzi et al., 2014), $\mathrm{Al}^{3+}$ activity was lower than the toxicity limits $\left(10^{-6} \mathrm{~mol} \mathrm{~L}^{-1}\right)$ recommended by Kinraide (1997) for the root growth of most plants. Below the 0.20 -m layer of soil, without the addition of pig slurry and with the application of 80 $\mathrm{m}^{3} \mathrm{ha}^{-1}$ pig slurry, the activity of $\mathrm{Al}^{3+}$ in the soil solution was close to the toxicity limits for crop growth (Figure 1), possibly due to low $\mathrm{pH}$ values (Table 2 ).

The $\mathrm{Al}^{3+}$ chemical species that shows greatest phytotoxic potential (Alleoni et al., 2010) was observed in larger proportions at deeper soil layers in all

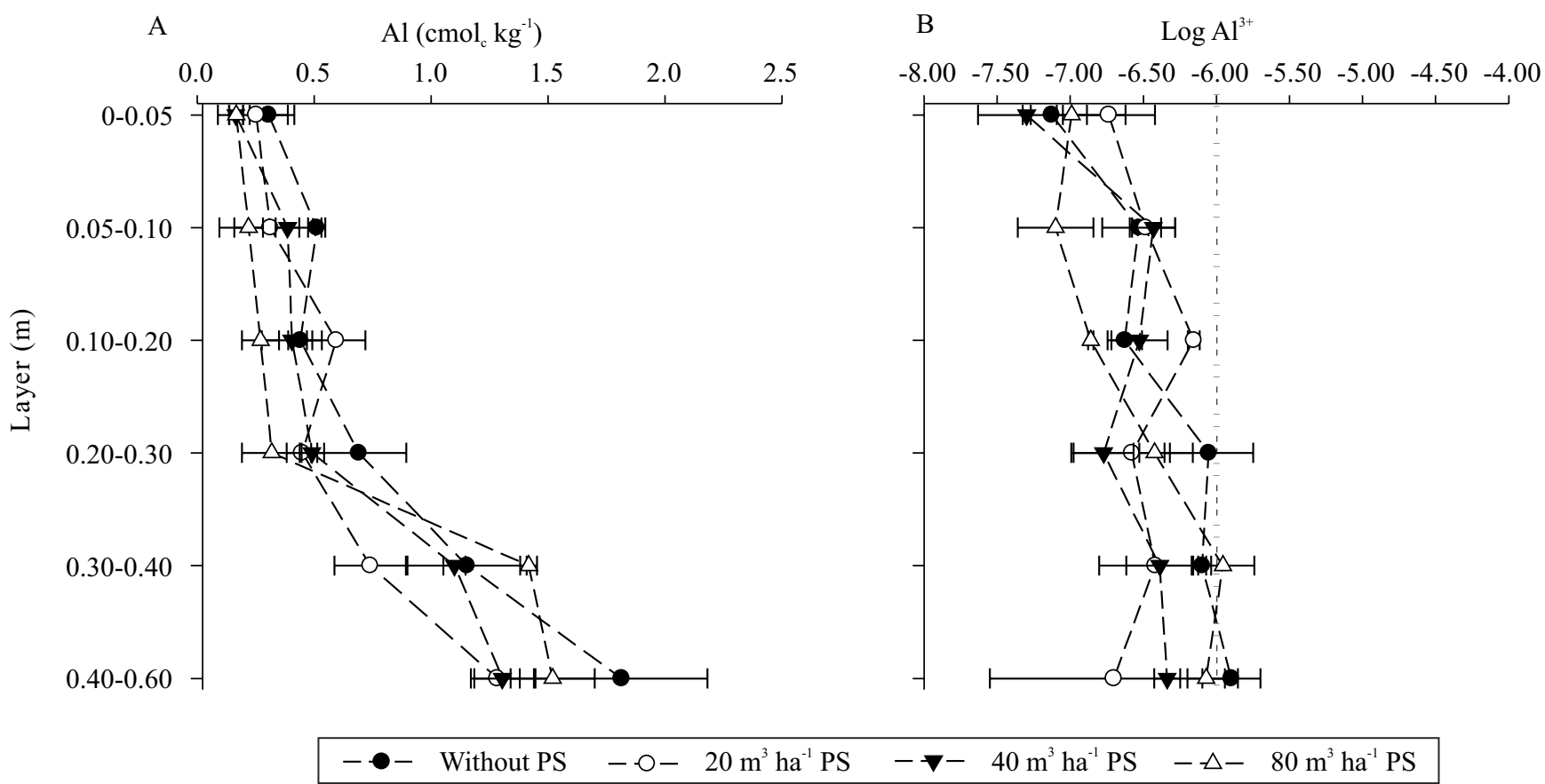

Figure 1. Contents of exchangeable $\mathrm{Al}(\mathrm{A})$ and activity of $\mathrm{Al}^{+3}$ species (B) in a Typic Hapludalf subjected to 19 applications of $0,20,40$, and $80 \mathrm{~m}^{3} \mathrm{ha}^{-1}$ pig slurry (PS), during eight years under no-tillage system. The dashed line corresponds to the toxicity limit (-6) for the growth of most crops. 
treatments (Figure 2). The percentage of $\mathrm{Al}^{3+}$ chemical species in the solution in the $0.40-0.60-\mathrm{m}$ layer was $40,46,38$, and $57 \%$ in the soil with pig slurry doses of $0,20,40$, and $80 \mathrm{~m}^{3} \mathrm{ha}^{-1}$, respectively. The lowest percentages of $\mathrm{Al}^{3+}$ were found in the $0.00-0.05-\mathrm{m}$ layer in all treatments and also at $0.05-0.10 \mathrm{~m}$ with the pig slurry dose of $80 \mathrm{~m}^{3} \mathrm{ha}^{-1}$. The percentage of $\mathrm{Al}^{3+}$ in the soil solution increased with depth in soil that received applications of 40 and $80 \mathrm{~m}^{3} \mathrm{ha}^{-1}$ pig slurry. This increase in the percentage of $\mathrm{Al}^{3+}$ in depth was due to the decrease in the concentration of organic and inorganic ligands, such as $\mathrm{DOC}$ and $\mathrm{SO}_{4}{ }^{2-}$ (Table 2), preserving $\mathrm{Al}$ in free form, coordinated by water molecules $\left[\mathrm{Al}\left(\mathrm{H}_{2} \mathrm{O}\right)_{6}\right]^{3+}$ (Rutkowska et al., 2015). Even in acidic soils, such as the one analyzed in the present study, where high Al percentages are expected to be found in free form, low or moderate $\mathrm{Al}^{3+}$ concentrations are usually observed in the solution of soils under no-tillage, while the complexes formed between $\mathrm{Al}, \mathrm{DOC}$, and inorganic anions represent the majority of Al species in the solution of topsoil layers (Alleoni et al., 2010).

The species of Al complexed with DOC (Al-DOC) predominated in the soil solution of most layers without the application of pig slurry, representing up to $55 \%$ of the Al species in the $0.30-0.40$ and $0.40-0.60$ $\mathrm{m}$ layers (Figure 2). When comparing the percentage of Al-DOC in the same layer between treatments, the highest rates were verified in soil without pig slurry application. This higher percentage of Al-DOC is due to the lower concentration of inorganic ligands, especially $\mathrm{H}_{2} \mathrm{PO}_{4}{ }^{-}$and $\mathrm{SO}_{4}{ }^{2-}$ in the soil without pig slurry addition (Table 2). The lower percentage of Al-DOC in the surface layers of the soil that received pig slurry applications, even with higher concentrations of DOC, indicates that $\mathrm{Al}$ has higher affinity for inorganic than

Table 2. Chemical properties of the soil solution of a Typic Hapludalf subjected to 19 applications of $0,20,40$, and $^{2} 8 \mathrm{~m}^{3}$ ha $^{-1}$ pig slurry, during eight years under no-tillage system.

\begin{tabular}{|c|c|c|c|c|c|c|c|c|c|c|c|c|c|}
\hline \multirow[t]{2}{*}{$\begin{array}{l}\text { Layer } \\
(\mathrm{m})\end{array}$} & $\mathrm{Al}$ & $\mathrm{Ca}$ & $\mathrm{Mg}$ & $\mathrm{Mn}$ & $\mathrm{K}$ & $\mathrm{Fe}$ & $\begin{array}{r}\mathrm{Cu} \\
\left.\mathrm{L}^{-1}\right)-\end{array}$ & $\mathrm{Zn}$ & $\mathrm{P}$ & $\mathrm{NO}_{3}^{-}$ & $\mathrm{SO}_{4}{ }^{2-}$ & $\mathrm{DOC}^{(1)}$ & $\mathrm{pH}$ \\
\hline & \multicolumn{13}{|c|}{ Application of $0 \mathrm{~m}^{3} \mathrm{ha}^{-1}$ pig slurry } \\
\hline $0.00-0.05$ & 0.13 & 52.71 & 32.22 & 0.40 & 6.44 & 0.08 & 0.019 & 0.059 & 0.09 & 547 & 10.4 & 17.6 & 5.76 \\
\hline $0.05-0.10$ & 0.19 & 53.25 & 12.08 & 0.45 & 4.38 & 0.13 & 0.017 & 0.030 & 0.06 & 324 & 6.9 & 20.1 & 5.28 \\
\hline $0.10-0.20$ & 0.08 & 40.86 & 22.92 & 0.64 & 2.71 & 0.08 & 0.019 & 0.045 & 0.09 & 471 & 14.0 & 11.5 & 4.99 \\
\hline $0.20-0.30$ & 0.20 & 72.45 & 42.95 & 1.43 & 2.59 & 0.07 & 0.017 & 0.057 & 0.13 & 810 & 2.8 & 7.8 & 4.71 \\
\hline $0.30-0.40$ & 0.22 & 59.37 & 52.66 & 0.88 & 2.64 & 0.08 & 0.016 & 0.058 & 0.12 & 220 & 6.9 & 13.9 & 4.75 \\
\hline \multirow[t]{2}{*}{$0.40-0.60$} & 0.21 & 43.89 & 37.15 & 0.70 & 2.36 & 0.09 & 0.019 & 0.074 & 0.10 & 346 & 1.6 & 13.5 & 3.90 \\
\hline & \multicolumn{13}{|c|}{ Application of $20 \mathrm{~m}^{3} \mathrm{ha}^{-1}$ pig slurry } \\
\hline $0.00-0.05$ & 0.17 & 177.72 & 131.81 & 0.48 & 9.15 & 0.02 & 0.026 & 0.129 & 0.27 & 1,292 & 53.4 & 29.5 & 5.49 \\
\hline $0.05-0.10$ & 0.19 & 81.24 & 55.01 & 0.53 & 4.47 & 0.01 & 0.001 & 0.073 & 0.15 & 565 & 17.2 & 11.9 & 4.46 \\
\hline $0.10-0.20$ & 0.15 & 73.13 & 44.81 & 0.33 & 2.20 & 0.01 & 0.001 & 0.058 & 0.11 & 517 & 11.5 & 4.5 & 4.53 \\
\hline $0.20-0.30$ & 0.07 & 53.98 & 30.60 & 0.27 & 2.15 & 0.04 & 0.006 & 0.049 & 0.11 & 363 & 11.0 & 4.1 & 5.05 \\
\hline $0.30-0.40$ & 0.12 & 53.12 & 36.11 & 0.75 & 2.31 & 0.07 & 0.017 & 0.050 & 0.12 & 353 & 3.8 & 4.1 & 5.17 \\
\hline \multirow[t]{2}{*}{$0.40-0.60$} & 0.07 & 45.93 & 27.36 & 0.41 & 1.73 & 0.07 & 0.017 & 0.037 & 0.10 & 284 & 2.9 & 3.7 & 5.17 \\
\hline & \multicolumn{13}{|c|}{ Application of $40 \mathrm{~m}^{3} \mathrm{ha}^{-1}$ pig slurry } \\
\hline $0.00-0.05$ & 0.13 & 147.79 & 127.42 & 1.83 & 10.36 & 0.02 & 0.091 & 0.205 & 1.20 & 987 & 62.0 & 54.5 & 5.72 \\
\hline $0.05-0.10$ & 0.18 & 148.21 & 125.18 & 0.72 & 7.61 & 0.01 & 0.045 & 0.130 & 0.67 & 871 & 35.3 & 30.3 & 4.76 \\
\hline $0.10-0.20$ & 0.13 & 71.00 & 57.40 & 0.55 & 2.44 & 0.02 & 0.027 & 0.062 & 0.24 & 1,224 & 61.0 & 4.9 & 4.75 \\
\hline $0.20-0.30$ & 0.05 & 53.39 & 43.50 & 0.23 & 1.64 & 0.00 & 0.026 & 0.053 & 0.14 & 623 & 21.9 & 5.3 & 4.98 \\
\hline $0.30-0.40$ & 0.08 & 46.06 & 37.16 & 0.28 & 1.30 & 0.00 & 0.022 & 0.052 & 0.13 & 264 & 7.6 & 4.1 & 4.72 \\
\hline \multirow[t]{2}{*}{$0.40-0.60$} & 0.07 & 34.32 & 28.97 & 0.35 & 1.22 & 0.01 & 0.021 & 0.053 & 0.11 & 326 & 6.4 & 4.6 & 4.53 \\
\hline & \multicolumn{13}{|c|}{ Application of $80 \mathrm{~m}^{3} \mathrm{ha}^{-1}$ pig slurry } \\
\hline $0.00-0.05$ & 0.22 & 506.51 & 375.09 & 1.87 & 26.77 & 0.03 & 0.214 & 1.164 & 3.52 & 2,487 & 364.0 & 104.2 & 5.23 \\
\hline $0.05-0.10$ & 0.14 & 274.90 & 152.17 & 3.69 & 18.15 & 0.01 & 0.065 & 0.537 & 2.66 & 2,103 & 324.2 & 49.2 & 5.18 \\
\hline $0.10-0.20$ & 0.09 & 122.27 & 113.08 & 0.38 & 4.47 & 0.01 & 0.035 & 0.124 & 0.43 & 1,082 & 50.9 & 7.8 & 5.37 \\
\hline $0.20-0.30$ & 0.08 & 62.33 & 52.32 & 0.24 & 2.07 & 0.01 & 0.023 & 0.052 & 0.15 & 457 & 22.2 & 2.7 & 4.90 \\
\hline $0.30-0.40$ & 0.16 & 48.81 & 37.00 & 0.40 & 1.65 & 0.01 & 0.033 & 0.071 & 0.11 & 397 & 15.3 & 5.7 & 4.05 \\
\hline $0.40-0.60$ & 0.10 & 47.31 & 33.47 & 0.56 & 1.66 & 0.01 & 0.027 & 0.069 & 0.11 & 542 & 18.1 & 2.5 & 4.07 \\
\hline
\end{tabular}

${ }^{(1)} \mathrm{DOC}$, dissolved organic carbon. 
organic ligands. However, the significant percentage of soluble Al complexed with organic compounds strengthen the importance of adopting agricultural practices that increase soil $\mathrm{C}$, particularly in soils with low concentrations of inorganic ligands, in order to reduce the potential toxicity of Al. The addition of plant residues, the adoption of conservation systems such as no-tillage, and the application of organic and animal waste are agricultural practices that promote

Without PS

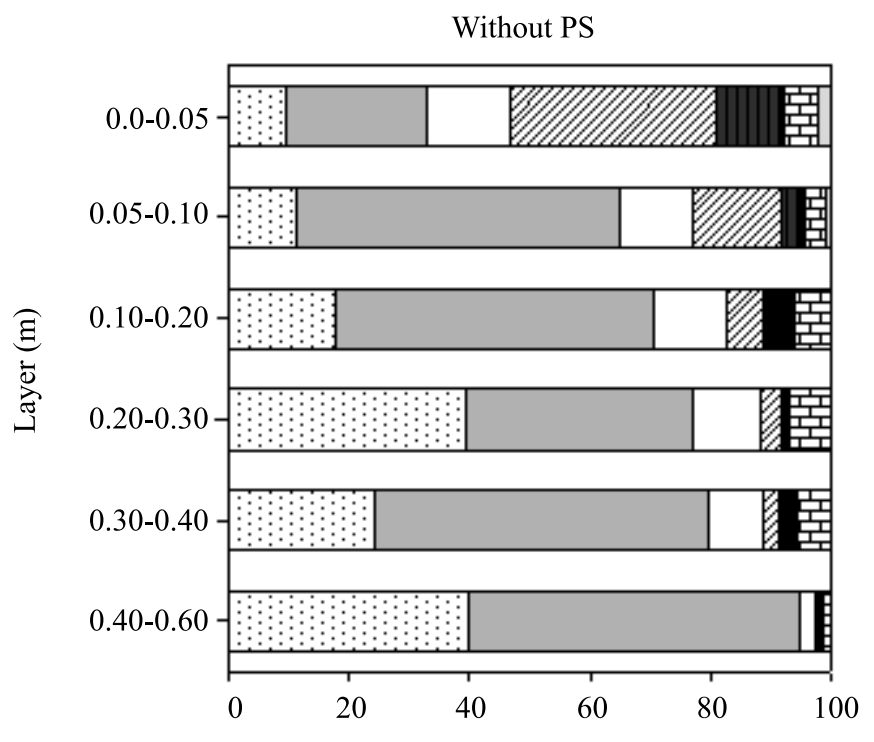

$40 \mathrm{~m}^{3} \mathrm{ha}^{-1} \mathrm{PS}$
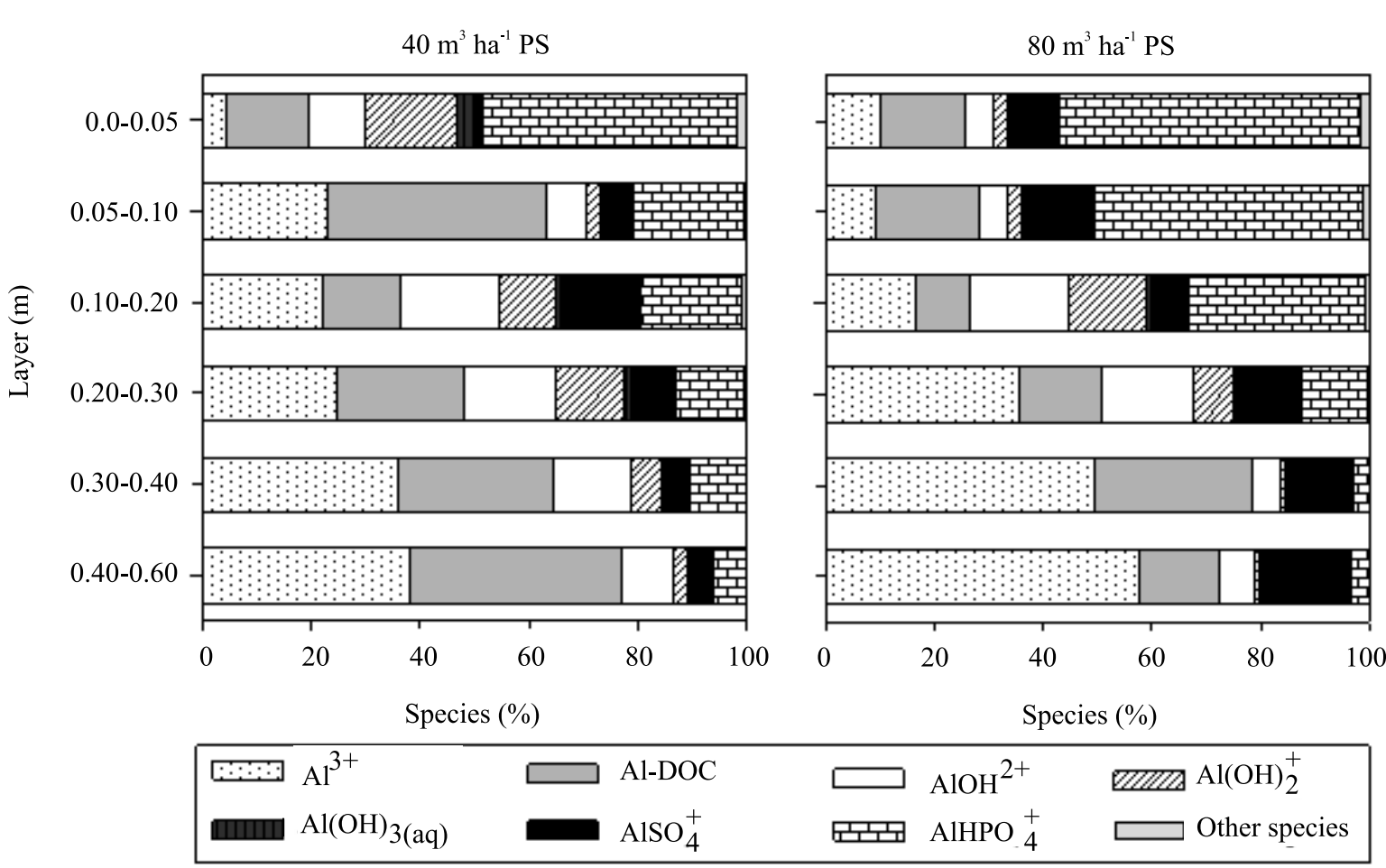

the increase of soil C (Zambrosi et al., 2007; Vieira et al., 2009; De Conti et al., 2016).

Pig slurry applications of 20, 40, and $80 \mathrm{~m}^{3} \mathrm{ha}^{-1}$ increased the proportion of $\mathrm{Al}$ complexed with $\mathrm{P}$ $\left(\mathrm{AlHPO}_{4}{ }^{+}\right)$, especially in the topsoil layers for all doses of pig slurry (Figure 2). The increase in the percentage of $\mathrm{AlHPO}_{4}{ }^{+}$in the $0.00-0.05$-m layer was 283,792 , and $943 \%$ with 20,40 , and $80 \mathrm{~m}^{3} \mathrm{ha}^{-1}$ pig slurry applications, respectively. In deeper soil layers, the increase in the

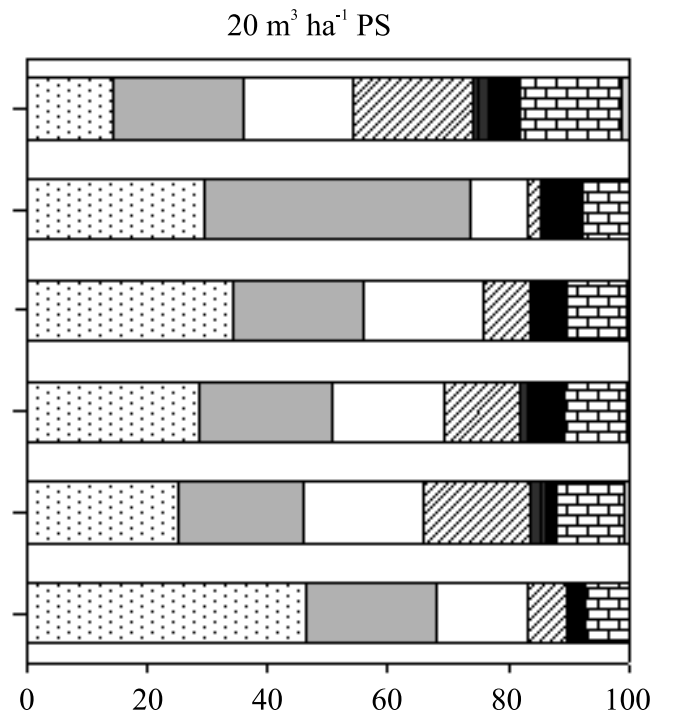

Figure 2. Al chemical species in the soil solution of a Typic Hapludalf subjected to 19 applications of $0,20,40$, and $80 \mathrm{~m}^{3} \mathrm{ha}^{-1}$ pig slurry (PS), during eight years under no-tillage system. Other species, $\mathrm{Al}(\mathrm{OH})_{4}{ }^{-}, \mathrm{Al}_{2}(\mathrm{OH})_{2}{ }^{4+}, \mathrm{Al}\left(\mathrm{SO}_{4}\right)^{2-}$, and $\mathrm{Al}_{2} \mathrm{PO}_{4}{ }^{3+}$. 
proportion of $\mathrm{AlHPO}_{4}^{+}$was more significant with 40 and $80 \mathrm{~m}^{3} \mathrm{ha}^{-1}$ pig slurry. Increased $\mathrm{AlHPO}_{4}{ }^{+}$can be explained by the increase in the concentration of $P$ in the solution of the surface layers of the soil that received pig slurry (Table 2). This is evidenced by the proximity of $\mathrm{AlHPO}_{4}{ }^{+}$and $\mathrm{P}$ in the $\mathrm{PCA}$, indicating correlations between the variables (Figure 3 ).

The slight effect of pig slurry applications on the percentage of $\mathrm{AlHPO}_{4}{ }^{+}$in depth is due to the low mobility of $\mathrm{P}$ in the soil profile, under no-tillage and surface applications of pig slurry (De Conti et al., 2015). High percentages of $\mathrm{AlHPO}_{4}{ }^{+}$in the $0.00-0.05$-m layer and a decrease in depth were also observed by Zambrosi et al. (2007) in an Oxisol under no-tillage subjected to gypsum application. Evaluating the effect of different organic materials in the distribution of $\mathrm{Al}$ species, in leachate of a sandy soil, Vieira et al. (2009) found high percentages of $\mathrm{AlHPO}_{4}{ }^{+}$in the soil that received the application of yard waste, compost of yard waste, and municipal waste. The formation of the chemical species $\mathrm{AlHPO}_{4}{ }^{+}$may reduce the risk of $\mathrm{Al}$ toxicity to plants by reducing the proportion of $\mathrm{Al}^{+3}$ species, but also reduces the availability of $\mathrm{P}$ to plants in the form of orthophosphate (Marschner, 2011). Therefore, high Al concentrations may hinder plant development, not only directly by toxicity, but also indirectly by decreasing the availability of elements such as P.

There was an increase in $\mathrm{AlSO}_{4}{ }^{+}$percentage in all the layers of the soil that received pig slurry, predominantly at deeper layers, such as $0.40-0.60 \mathrm{~m}$, where the

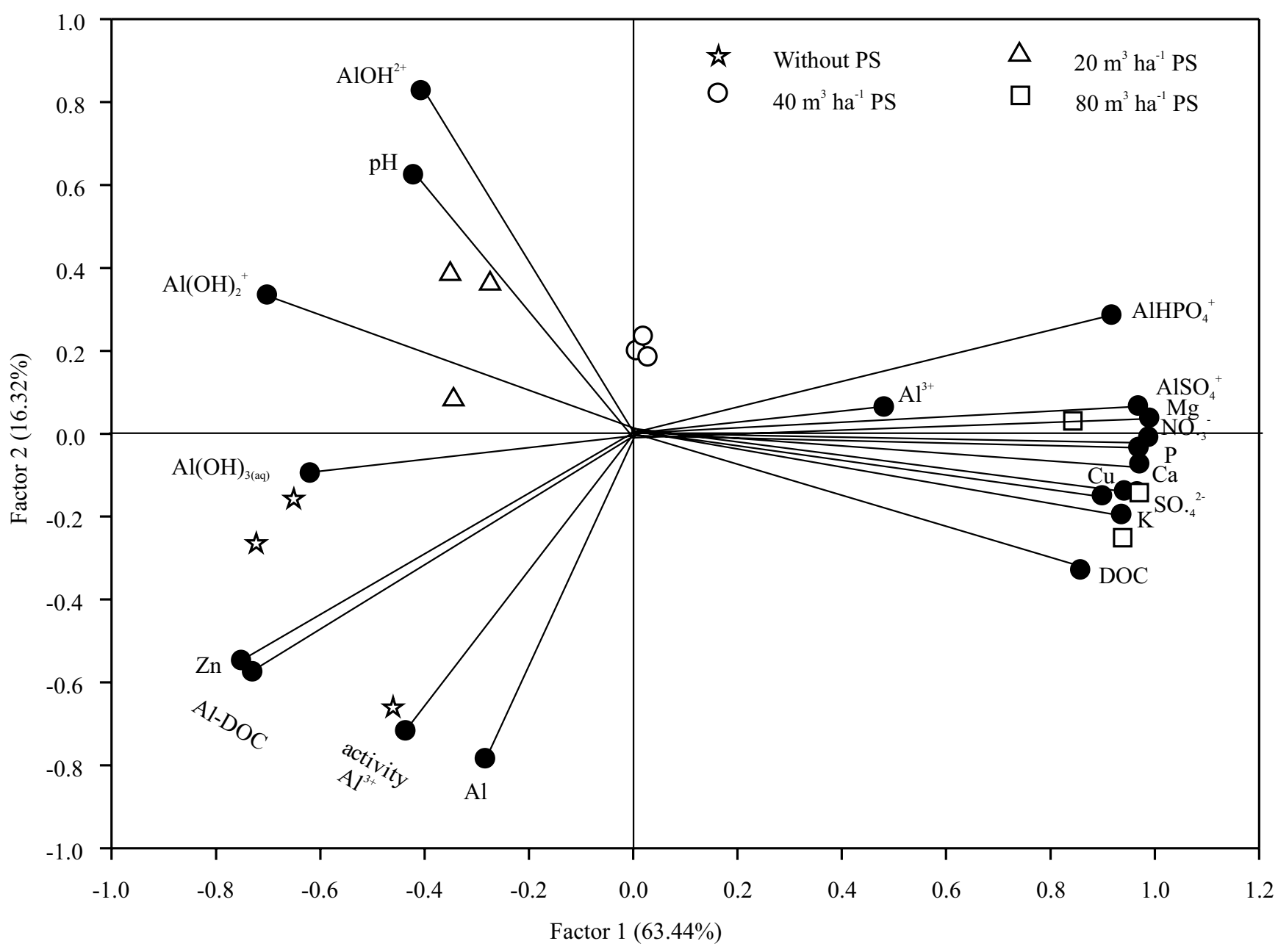

Figure 3. Relationship between principal component 1 (factor 1) and principal component 2 (factor 2) of the Al chemical species and the chemical elements determined in the soil solution of a Typic Hapludalf subjected to 19 applications of 0 , 20, 40, and $80 \mathrm{~m}^{3} \mathrm{ha}^{-1}$ pig slurry (PS), during eight years under no-tillage system. Al-DOC, Al complexed with dissolved organic carbon (DOC). 
increase was of 279,445 , and $1,556 \%$ for pig slurry doses of 20, 40, and $80 \mathrm{~m}^{3} \mathrm{ha}^{-1}$, respectively (Figure 2). The highest percentage of $\mathrm{AlSO}_{4}^{+}$can be attributed to the increase in the concentration of $\mathrm{SO}_{4}{ }^{2-}$ in most of the layers of the soil that received pig slurry (Table 2). The correlation between the concentration of $\mathrm{SO}_{4}{ }^{2-}$ and the $\mathrm{AlSO}_{4}{ }^{+}$species is evidenced in the proximity of the two variables in the PCA (Figure 3). Five years after the application of gypsum in a dystrophic clayey Rhodic Hapludox under no-tillage, Zambrosi et al. (2007) reported that $\mathrm{AlSO}_{4}{ }^{+}$represented less than $1 \% \mathrm{Al}$ in the soil solution. The small percentage of $\mathrm{AlSO}_{4}{ }^{+}$found probably was due to the low $\mathrm{SO}_{4}{ }^{-2}$ concentration in the soil solution, compared with that in the soils that received 20,40, and $80 \mathrm{~m}^{3} \mathrm{ha}^{-1}$ pig slurry applications. The $\mathrm{AlOH}^{2+}$ and $\mathrm{Al}(\mathrm{OH})_{2}^{+}$species had reduced percentages at $0.00-0.05$ and $0.05-0.10 \mathrm{~m}$ when using 40 and $80 \mathrm{~m}^{3}$ ha $^{-1}$ pig slurry, while the application of $20 \mathrm{~m}^{3} \mathrm{ha}^{-1}$ pig slurry promoted the reduction of $\mathrm{Al}(\mathrm{OH})_{2}{ }^{+}$exclusively in the $0.00-0.05-\mathrm{m}$ layer (Figure 2). The reduction in the percentage of these Al species indicates lower risk of toxicity in soils that received pig slurry, especially in higher doses. After $\mathrm{Al}^{3+}$, the $\mathrm{AlOH}^{2+}$ and $\mathrm{Al}(\mathrm{OH})_{2}{ }^{+}$species are more harmful to the plant root system (Bloom \& Erich, 1995). A higher percentage of the $\mathrm{Al}(\mathrm{OH})_{3(\mathrm{aq})}$ species was observed in the $0.00-0.05-\mathrm{m}$ soil layer without pig slurry addition, which represented $10.8 \%$ of the Al in the soil solution, possibly due to the high $\mathrm{pH}$ value in this layer (Table 2). The percentages of hydroxylated species of $\mathrm{Al}$ in the solution are strongly affected by $\mathrm{pH}$, as shown in the correlation between the hydroxylated $\mathrm{Al}$ species and the $\mathrm{pH}$ in the PCA. Rutkowska et al. (2015) also verified predominantly hydroxylated $\mathrm{Al}$ species, mainly $\mathrm{Al}(\mathrm{OH})_{4}{ }_{4}$, in the solution of soils whose $\mathrm{pH}$ increased as a consequence of liming. Other species in the soil solution, such as $\mathrm{Al}(\mathrm{OH})_{4}^{-}, \mathrm{Al}_{2}(\mathrm{OH})_{2}{ }^{4+}, \mathrm{Al}\left(\mathrm{SO}_{4}\right)_{2}{ }^{-}$and $\mathrm{Al}_{2} \mathrm{PO}_{4}{ }^{3+}$, were found in small percentages.

The distribution of scores by the PCA, in each group along factor 1 , which accounts for most of the data variability $(63.44 \%)$, is related to the dose of pig slurry, separating the $80 \mathrm{~m}^{3} \mathrm{ha}^{-1}$ dose from the $20 \mathrm{~m}^{3} \mathrm{ha}^{-1}$ dose and the soil without pig slurry addition (Figure 3). The species $\mathrm{AlHPO}_{4}{ }^{+}$and $\mathrm{AlSO}_{4}{ }^{+}$were the ones that most contributed to separating the $80 \mathrm{~m}^{3} \mathrm{ha}^{-1}$ dose. Conversely, the hydroxylated species (Al-OH), correlated with the $\mathrm{pH}$ of the soil solution, were the variables with the greatest contributions to the group formed by the soil without pig slurry application and with the dose of $20 \mathrm{~m}^{3} \mathrm{ha}^{-1}$. The increase in the percentage of the Al-OH species with the increase in the dose of limestone was observed by Alleoni et al. (2010) on a Rhodic Haplustox in the Midwestern region of Brazil.

The decrease in the percentages of the potentially toxic $\mathrm{Al}$ species $\mathrm{AlOH}^{2+}$ and $\mathrm{Al}(\mathrm{OH})_{2}{ }^{+}$and the increase of species complexed with inorganic ligands in the soil solution with the application of pig slurry indicate a possible reduction in the phytotoxicity of $\mathrm{Al}$ and a lower response of the crops to liming in areas with a history of pig slurry applications, as significant amounts of $\mathrm{Ca}$ and $\mathrm{Mg}$ were also added (Table 1).

\section{Conclusions}

1. The application of pig slurry does not change the exchangeable $\mathrm{Al}$ content in the soil and $\mathrm{Al}^{3+}$ activity in the soil solution.

2. The low $\mathrm{Al}^{3+}$ activity in the topsoil layers does not present risk of toxicity for most crops.

3. Pig slurry applications increase the proportion of the $\mathrm{AlHPO}_{4}{ }^{+}$and $\mathrm{AlSO}_{4}{ }^{+}$species in the soil solution, by increasing the concentration of soluble inorganic ligands.

\section{Acknowledgments}

To Conselho Nacional de Desenvolvimento Científico e Tecnológico (CNPq), to Coordenação de Aperfeiçoamento de Pessoal de Nível Superior (Capes), and to Fundação de Amparo à Pesquisa do Estado do Rio Grande do Sul (Fapergs), for financial resources.

\section{References}

ALLEONI, L.R.F.; CAMBRI, M.A.; CAIRES, E.F.; GARBUIO, F.J. Acidity and aluminum speciation as affected by surface liming in tropical no-till soils. Soil Science Society of America Journal, v.74, p.1010-1017, 2010. DOI: 10.2136/sssaj2009.0254.

BLOOM, P.R.; ERICH, M.S. The quantification of aqueous aluminum. In: SPOSITO, G. (Ed.). The environmental chemistry of aluminum. $2^{\text {nd }}$ ed. Boca Raton: Lewis Publ., 1995. p.1-38.

BORTOLUZZI, E.C.; PARIZE, G.L.; KORCHAGIN, J.; SILVA, V.R. da; RHEINHEMER, D. dos S.; KAMINSKI, J. Soybean root growth and crop yield in reponse to liming at the beginning of a no-tillage system. Revista Brasileira de Ciência do Solo, v.38, p.262-271, 2014. DOI: 10.1590/S0100-06832014000100026. 
BRAAK, C.J.F. ter; SMILAUER, P. CANOCO reference manual and CanoDraw for Windows user's guide: software for canonical community ordination (version 4.5). Ithaca: Microcomputer Power, 2002. 500p.

CLAESSEN, M.E.C. (Org.). Manual de métodos de análise de solos. 2.ed. rev. e atual. Rio de Janeiro: Embrapa-CNPS, 1997. 212p.

COUTO, R. da R.; SANTOS, M. dos; COMIN, J.J.; MARTINI, L.C.P.; GATIBONI, L.C.; MARTINS, S.R.; BELLI FILHO, P.; BRUNETTO, G. Environmental vulnerability and phosphorus fractions of areas with pig slurry applied to the soil. Journal of Environmental Quality, v.44, p.162-173, 2015. DOI: 10.2134/ jeq2014.08.0359.

DE CONTI, L.; CERETTA, C.A.; FERREIRA, P.A.A.; LORENSINI, F.; LOURENZI, C.R.; VIDAL, R.F.; TASSINARI, A.; BRUNETTO, G. Effects of pig slurry application and crops on phosphorus content in soil and the chemical species in solution. Revista Brasileira de Ciência do Solo, v.39, p.774-787, 2015. DOI: $10.1590 / 01000683$ rbcs20140452.

DE CONTI, L.; CERETTA, C.A.; FERREIRA, P.A.A.; LOURENZI, C.R.; GIROTTO, E.; LORENSINI, F.; TIECHER, T.L.; MARCHEZAN, C.; ANCHIETA, M.A.; BRUNETTO, G. Soil solution concentrations and chemical species of copper and zinc in a soil with a history of pig slurry application and plant cultivation. Agriculture, Ecosystems and Environment, v.216, p.374-386, 2016. DOI: 10.1016/j.agee.2015.09.040.

FEPAM. Fundação Estadual de Proteção Ambiental Henrique Luis Roessler - RS. Programas e Projetos: Gestão de Ativos Ambientais. Available at: <http://www.fepam.rs.gov.br/ programas/gestao_ativos.asp>. Accessed on: May 222008.

GRIMM, D.M.; AZARRAGA, L.V.; CARREIRA, L.A.; SUSETYO, W. Continuous multiligand distribution model used to predict the stability constant of $\mathrm{Cu}$ (II) metal complexation with humic material from fluorescence quenching data. Environmental Science and Technology, v.25, p.1427-1431, 1991. DOI: 10.1021/es00020a010.

GUSTAFSSON, J.P. Visual Minteq. Available at: <http://www.lwr. kth.se/english/oursoftwaer/Vminteq>. Accessed on: Nov. 122012.

KINRAIDE, T.B. Reconsidering the rhizotoxicity of hydroxyl, sulphate, and fluoride complexes of aluminium. Journal of Experimental Botany, v.48, p.1115-1124, 1997.

LOURENZI, C.R.; CERETTA, C.A.; SILVA, L.S. da; GIROTTO, E.; LORENSINO, F.; TIECHER, T.L.; DE CONTI, L.; TRENTIN, G.; BRUNETTO, G. Nutrients in soil layers under no-tillage after successive pig slurry applications. Revista Brasileira de Ciência do Solo, v.37, p.157-167, 2013. DOI: 10.1590/S010006832013000100016.

MARSCHNER, H. (Ed.). Marschner's mineral nutrition of higher plants. $3^{\text {rd }}$ ed. London: Academic Press, 2011.

NOGUEIROL, R.C.; MONTEIRO, F.A.; AZEVEDO, R.A. Tropical soils cultivated with tomato: fractionation and speciation of Al. Environmental Monitoring and Assessment, v.187, p.160167, 2015. DOI: 10.1007/s10661-015-4366-0.

NOLLA, A.; ANGHINONI, I. Atividade e especiação química na solução afetadas pela adição de fósforo em Latossolo sob plantio direto em diferentes condições de acidez. Revista Brasileira de Ciência do Solo, v.30, p.955-963, 2006.

RUTKOWSKA, B.; SZULC, W.; HOCH, M.; SPYCHAJFABISIAK, E. Forms of Al in soil and soil solution in a long-term fertilizer application experiment. Soil Use and Management, v.31, p.114-120, 2015. DOI: 10.1111/sum.12150.

SANTOS, H.G. dos; JACOMINE, P.K.T.; ANJOS, L.H.C. dos; OLIVEIRA, V.A. de; LUBRERAS, J.F.; COELHO, M.R.; ALMEIDA, J.A. de; CUNHA, T.J.F.; OLIVEIRA, J.B. de. Sistema brasileiro de classificação de solos. 3.ed. rev. e ampl. Brasília: Embrapa, 2013. 353p.

SILVA, L.S.; BOHNEN, H. Mineralização de palha de milho e adsorção de carbono, cálcio, magnésio e potássio em substratos com caulinita natural e goethita sintética. Revista Brasileira de Ciência do Solo, v.25, p.289-296, 2001. DOI: 10.1590/S010006832001000200005 .

SMITH, R.M.; MARTELL, A.E.; MOTEKAITIS, R.J. NIST critically selected stability constants of metal complexes database. Version 7.0. Gaithersburg: National Institute of Standards and Technology, 2003. (NIST standard reference database, 46).

STRECK, E.V.; KÄMPF, N.; DALMOLIN, R.S.D.; KLAMT, E.; NASCIMENTO, P.C. do; SCHNEIDER, P.; GIASSON, E.; PINTO, L.F.S. Solos do Rio Grande do Sul. 2.ed. rev. e ampl. Porto Alegre: UFRGS: EMATER/RS-ASCAR, 2008. 222p.

TEDESCO, M.J.; GIANELLO, C.; BISSANI, C.A.; BOHNEN, H.; VOLKWEISS, S.J. Análises de solo, plantas e outros materiais. 2.ed. rev. e ampl. Porto Alegre: UFRGS, 1995. 174p. (UFRGS. Boletim técnico, 5).

VEIGA, M. da; PANDOLFO, C.M.; BALBINOT JUNIOR, A.A.; SPAGNOLLO, E. Chemical attributes of a Hapludox soil after nine years of pig slurry application. Pesquisa Agropecuária Brasileira, v.12, p.1766-1773, 2012. DOI: 10.1590/S0100204X2012001200013.

VIEIRA, F.C.B.; HE, Z.L.; WILSON, C.; BAYER, C. Speciation of aluminum in solution of an acidic sandy soil amended with organic composts. Communications in Soil Science and Plant Analysis, v.40, p.2094-2110, 2009. DOI: 10.1080/00103620902960617.

WOLT, J.D. Obtaining soil solution: laboratory methods. In: WOLT, J.D. Soil solution chemistry: applications to environmental science and agriculture. New York: J. Wiley, 1994. 345p.

ZAMBROSI, F.C.B.; ALLEONI, L.R.F.; CAIRES, E.F. Aplicação de gesso agrícola e especiação iônica da solução de um Latossolo sob sistema plantio direto. Ciência Rural, v.37, p.110-117, 2007. DOI: $10.1590 / \mathrm{S} 0103-84782007000100018$.

Received on August 15, 2016 and accepted on June 13, 2017 